\title{
Financial Reporting By Small and Medium Scale Enterprises in Nigeria
}

\author{
Omoregie N.A.E., Adeparubi O.O. (B.Sc), Iboi P. E. (B.Sc) \\ (M.Sc, MBA, M.Ed, B.Sc, PGDE)Department of Accounting, Faculty of Management Sciences, Ambrose Alli \\ University, Ekpoma, Edo State. \\ Department of Accounting, Faculty of Business Studies, Rufus Giwa Polytechnic, Owo, Ondo State. \\ Department of Accounting, Faculty of Management Sciences, Ambrose Alli University, Ekpoma, Edo State.
}

\begin{abstract}
Over the years, there has been a controversy as to whether the current financial reporting system for small and medium scale enterprises (hereafter, SMEs) is adequate. This controversy has been encountered in various countries of the world, Nigeria inclusive. The main objective of this study is to examine the opinion of users of SME financial statements, the accountants that prepare SME financial statements as well as other stakeholders' in SME financial reporting on whether or not SMEs in Nigeria should have their own set of financial reporting standards, it is therefore aimed at looking into financial reporting by SMEs in various countries and in Nigeria in particular. The study was a survey type which used questionnaires as means of collecting data. Data collected were analyzed by the use of non-parametric test of hypothesis, the chi-square. It was discovered that while there was a high preference for the use of two sets of Generally Accepted Accounting Principles (GAAP) for preparing financial reports, the most preferred was the current financial reporting system of a single set of GAAP with some exclusions for SMEs. The study recommended that the current financial reporting system should be continued but with improvements so as to reduce the weaknesses contained in the system.
\end{abstract}

Key words: Accounting Standards, Generally Accepted Accounting Principles (GAAP), Differential Reporting, Compliance Cost.

\section{Introduction}

Financial reporting can be seen as a summary of the performance or capacity of a business in raising, handling and using money (Sacco, 1997). Financial reports (or financial statements) are formal records of a business' financial activities. They provide an overview of a business' financial condition in both short and long term (Wikipedia, 2008). Financial reporting however goes beyond financial statements. It involves providing to users, all information; quantitative or qualitative on the enterprise to allow those users make economic decisions.

Financial reporting for small and medium scale enterprises (SMEs) has been the subject of much debate and concern by accounting bodies (institutes) in Canada, the United States, the United Kingdom, New Zealand, Australia and other countries. The main issue is whether there should be one set of standards for all companies or two sets of standards (one for big companies and one for SMEs).

Maingot and Zeghal (2006) observed that the problem of financial accounting and reporting for SMEs has generated much discussion in the accounting literature over the past years in many countries. There seems to be a broad support for differential reporting for disclosure and presentation. Small and medium scale enterprises differ from public corporations. Public companies engage in complex transactions like financial instruments that are not reflected in the transactions of SMEs. The Generally Accepted Accounting Principles (GAAP) used to prepare the financial statements of the public companies was designed for these larger corporations. SMEs, at present, have to use the same GAAP to prepare their accounts notwithstanding the fact that public companies financial reports are used by millions of external users, and therefore these public companies can bear the cost of preparing and presenting their reports. SME reports on the other hand, have very few users (these include: owners/managers, bankers, taxation authorities and perhaps venture capitalists). Also, the cost of producing these accounts using existing GAAP designed primarily for large companies is very high and burdensome. The cost is sometimes the result of the SME using its own managers or internal accountants to prepare the financial reports. However, SMEs very often use practitioners to prepare their financial reports. There is consequently both a cost to the SME (fee charged) and a cost to the practitioners (constantly updating knowledge of GAAP), which causes continual increment in overall costs.

In Nigeria, the only concession made for small and medium scale enterprises SMEs or 'small companies is that they can deliver modified financial statements to the Corporate Affairs Commission (section 350 of Companies and Allied Matters Act (CAMA) 1990 as amended to date. These modified financial statements will exclude: statement of cash flows, statement of accounting policies, value added statement and 
five year financial summary (Ilaboya, 2005:177). In view of this, the aim of this study is to obtain and evaluate accounting practitioners' views (opinions) about the adequacy and cost effectiveness of the present financial reporting system for small and medium scale enterprises (SMEs) and as a result, the following hypotheses were formulated:

$\mathbf{H}_{\mathbf{0}}$ 1: The costs of adopting a single set of GAAP without exclusions do not outweigh its benefits.

$\mathbf{H}_{\mathbf{O}}$ 2: The costs of adopting a single set of GAAP with exclusions from certain standards for SMEs do not outweigh its benefits.

$\mathbf{H}_{\mathbf{O}} 3$ : The costs of adopting two sets of GAAP (big GAAP and little GAAP) do not outweigh its benefits.

\section{Review Of Literature}

It is important to note that the definition of small and medium scale enterprises SMEs is relative, implying that there is no clear cut definition of SMEs universally. Industries that are regarded as small or medium in the developed countries could be large in developing countries. Therefore, each country has tried to define small and medium scale enterprises SMEs to suit its environment and purpose, considering the level of industrial development in the country, and also designed to meet the administrative and other needs of the country. The definition is usually based on criteria such as number of employees, capital investment, sales volume (turnover) motive, power and total assets.

In the light of the above, a small scale business was defined as one with relatively small shares or owners or part-owners in a personalized way which became owners not through the medium of formalized management structure and is independent, implying that it does not form part of a large enterprise nor its managers subject to outside control when taking major decisions.

In Nigeria, the definition of SMEs varies from time to time and from institution to institution. According to the Third National Development Plan, 'manufacturing establishments employing less than ten persons or whose investment in machinery and equipment do not exceed six hundred thousand naira are referred to as small scale industries'.

The Central Bank of Nigeria (CBN), monetary policy circular No.22 of 1988, defined SMEs (excluding general commerce) as enterprises in which total investment (excluding land and working capital) did not exceed five hundred thousand naira and/or annual turnover did not exceed five million naira. According to NERFUND, SMEs are defined as enterprises whose fixed assets other than land but including the cost of new investment and the finance do not exceed ten million naira.

The Nigerian Industrial Development Bank (now known as Bank of Industry - BOI) defined medium scale industry as one whose project cost (investment and working capital) are above seven hundred and fifty thousand naira but not greater than three million naira. Also under the Nigerian Bank for Commerce and Industry (NBCI) World Bank assisted loan scheme, a medium scale enterprise is regarded as one whose project (investment plus working capital) costs are above seven hundred and fifty thousand naira but not exceeding three million naira.

Ogbe (1985) claimed that we all know that a medium scale enterprise is bigger than one of a small scale but not large enough to qualify as large.

Lastly, by definition of statute, section 351(1) of CAMA 1990 as amended defines a small company as one satisfying the following conditions:

* It is a private company having share capital

* The amount of its annual turnover is not more than two million naira or such amount as may be fixed by the Corporate Affairs Commission (CAC).

* Its net assets value is not more than one million naira or such amount as may be fixed by the CAC.

* None of its members is an alien.

* None of its members is a government or government corporation or agency or its nominee.

* Directors between them hold not less than fifty one percent of its equity share capital.

\section{Financial reporting by small and medium scale enterprises}

According to the study carried out by Maingot and Zeghal, the purposes of small and medium scale enterprises (SMEs) financial reports obtained are:

* For tax purposes

- Bank purposes

* Review of performance

* Planning decision

The results obtained from the study seemed to imply that SMEs use financial statements primarily for external rather than internal constituencies. In Canada, similar to public companies, SMEs must file their tax returns based on their financial statements both at the federal government and the provincial government levels. There are many very complex forms to be filled out and this might explain why SMEs focus on taxation as the main purpose of financial statements. 
Banks insist on receiving financial statements before they grant loans and SMEs appear to obtain their financing through bank loans. SMEs use the financial reports as a planning tool but this only ranks fourth by the users of the reports. This can be perhaps explained by the fact that the SMEs use budgeted information for planning purposes.

Several countries have several reporting standards (or accounting standards) for SMEs. They have provided these reporting standards based on several reasons which include reduction of burden on SMEs, the fact that SMEs have fewer users or user groups, the fact that several provisions of the fuller standard do not pertain to SMEs and a host of other factors. This seems to be bringing into place 'differential reporting' where larger corporations have their own reporting standards and SMEs have theirs.

\section{Objectives of Financial Reporting}

The objectives of financial reporting are numerous. Generally, financial reporting aims to:

* Furnish information useful in making investment and credit decisions.

* Provide information useful in assessing cash flow prospects.

- Provide information about business resources, claims to those resources, and changes in them.

* Provide information about management discharge of responsibility.

Originally, the purpose of financial reporting was to evaluate management's honesty and nothing more. Jameson (1999) claims that the purpose of financial reporting is no longer just the appraisal of stewardship: that the needs of users have evolved beyond those satisfied by purely reporting on post transactions and current solvency.

The Accounting Standards Board (ASB) gives more importance to decision - usefulness than stewardship. The ASB in their Statement of Principles (1999), have decided the objectives of financial reporting is to provide information about the reporting entity's financial performance and financial position that is useful to a wide range of users for assessing the stewardship of the entity's management and for making economic decisions.

\section{Sources of Authority Guiding Financial Reporting}

Different countries have developed their own accounting principles over time, making international comparisons of companies difficult. To ensure uniformity and comparability between financial statements prepared by different companies, a set of guidelines and rules are commonly used. Commonly referred to as Generally Accepted Accounting Principles (GAAPs), these set of guidelines provide the basis for the presentation of financial reports. The need for uniform accounting standards was first noticed after the stock market crash of 1929. Many adduced the reason for the crash and subsequent high rate of inflation to misleading accounting information. The first standard setting body was a committee of the American Institute of Accounting called Committee on Accounting Procedure (CAP), which was formed in 1938, and up to 1959 when it was replaced by the Accounting Principles Board (APB), CAP had issued 51 Accounting Research Bulletins (ARBs). The APB operated up to 1973 when it was replaced by the Financial Accounting Standards Board (FASB). The FASB was the first standard setting body with representatives outside the accounting profession (Ilaboya, 2005).

Recently, there has been a push towards standardizing accounting rules made by the International Accounting Standards Board (IASB). IASB develops International Financial Reporting Standards (IFRS) that have been adopted by Australia, Canada, and the European Union (for publicly quoted companies only), are under consideration in South Africa and other countries. The United States FASB has made a commitment to converge U.S. GAAP and IFRS over time. In Nigeria, the preparation and presentation of financial statements is a statutory duty vested in the company directors by virtue of section 334(1) of Companies and Allied Matters Act 1990 as amended. These statements are prepared in accordance with the provisions of some basic principles - rules, regulations, policies and procedures which are either, statutory, supervisory or obligatory. The sources of authority can be classified as follows:

\section{* Generally Accepted Accounting Principles (GAAP)}

These are conventions and rule of thumb practices which have developed through the ages as concerning accounting practices. According to Spiceland et al (2001:9) as cited in Ilaboya (2005), GAAPs are a set of dynamic guidelines (both broad and specific that companies should follow when measuring and reporting information in their financial statements and related notes. GAAPs cannot be legally enforceable because they are not backed by law. The enforcement of GAAPs is persuasive rather than compulsory.

\section{* Legislation}

The legal sources of authority are the minimum corporate requirements which origin can be traced to the period when ownership was divested from control of limited liability companies. Though a fundamental source of authority, suffice to mention that the law cannot exhaust the content of preparation of a financial statement. The dynamism of the global corporate environment has a resultant effect on corporate reporting. As 
the environment of business changes, the reporting mode of the business will also follow suit. There are different laws in place to shape the requirements of corporate reporting. For instance, the activity of corporate organizations in Nigeria is supervised by the Corporate Affairs Commission (CAC) via the CAMA 1990. Also, other regulations issued by government include:

- $\quad$ Banks and other Financial Institutions Decree 1991

- $\quad$ Insurance Decree 1997

- $\quad$ Nigeria Deposit Insurance Decree 1988

- Judicial precedence

Unlike GAAPs, compliance with legal provisions is compulsory and binding on all companies in Nigeria. Legislation as a source of authority is however limited by the fact that it is not easily reviewed. Changes in accounting practices are not easily reflected in the law because the due process must be observed.

* $\quad$ Accounting Standards

Standards are rules comprising of best practices issued from time to time by a duly empowered body. The standard setting organizations function by reviewing existing accounting principles and practices and recommend the best through a standard. In Nigeria, the standard setting body is the Nigerian Accounting Standards Board (NASB) which came into operational existence on $9^{\text {th }}$ September, 1982 with 13 member bodies cutting across all facets of the national economy. The board identifies areas where a measure of uniformity is required so as to ensure a high level of uniformity which aids corporate comparability.

\section{International financial reporting standards for small and medium scale enterprises}

In 2001, the accounting press raised the issue of an International Financial Reporting Standard for Small and Medium Scale Enterprises (FRSSE). From 2005, all European Union linked companies have started to produce accounts in accordance with International Accounting Standards (IAS). This has encouraged accounting firms and professional bodies to suggest that SMEs require an IAS. They argued that this should not be dissimilar to the UK's FRSSE but should at least take the perspective of the IAS as its starting point. At the same time, there has been pressure mounting from the small firms lobbying for the development of a standalone set of simplified international standard (Sleigh-Johnson, 2001).

In response to the need for international standards for SMEs in February 15, 2006, the International Accounting Standards Board (IASB) issued for public comment the exposure draft of its International Financial Reporting Standards (IFRS) for SMEs. The stated aim of the proposed standard is to provide a simplified, self-contained set of accounting principles derived from the full IFRS to be used by smaller, non-listed companies. If this proposal is adopted, the full IFRS would become mainly of interest for listed companies, although SMEs could make reference to the more expensive set of standards as necessary or desirable.

The perceived need for a stand-alone set of simplified standards has become increasing manifest in recent years, and the Financial Accounting Standards Board (FASB) is also weighing the development of such a streamlined set of financial reporting requirement. This latest development comes after about a decade of a similar undertaking in the United Kingdom, where FRSSE have been successfully implemented (Epstein and Jermakowicz, 2007).

The support for the IASB's project from national accounting standards setters throughout the world stems mostly from the widely perceived complexity of the full IFRS, and from the different statutory requirements for financial reporting in many countries, compared to the United States. The complexity of the full IFRS imposes a high compliance cost. In addition, most countries legally require SMEs to file statutory financial statements prepared in accordance with national GAAP, and to make them available to all users. It is also believed that the IFRS for SMEs would allow companies as well as countries an easier transition to the full IFRS. Some commentators are not in support of the approach taken in the development of IFRS for SMEs (or private companies). They argued that, rather than simply streamlining existing standards, the IASB should have taken a user-based, more conceptual approach in creating differential reporting for SMEs. They insist that fundamental differences exist between the objectives of financial reporting for SMEs (which is primarily focused on stewardship) and those of reporting by large public companies, and that these differences should be incorporated into the conceptual framework.

Those who oppose having a separate set of standards for SMEs believe that all entities should follow the same basic accounting principles for the preparation of general purpose financial statements, whether the IFRS or US GAAP. Some have concluded that the problem is not that SMEs need simpler accounting, but that all entities need reporting requirements that are less complex and more principle-based. Some opponents also note that SME standards would adversely affect accounting education, by shifting the focus from preparing professionals to choose the best means of reporting the economic effects of any given transaction or event, to merely following what 'a single-solution rule book says' (Epstein and Jermakowicz). A worst-case scenario result would be a two-tiered accounting profession, wherein some practitioners would be seen as incapable of handling assignments other than 'little GAAP' assignment. 
Because the IASB lacks the power to enforce the use of its standards, the adoption of IFRS for SMEs will be a matter for each country to decide; that is, a country's government legislators and regulators, an independent standard setting body or a professional accounting body. Each country would have to set its criteria to establish eligibility.

\section{Financial Reporting By Small and Medium Scale Enterprises in Nigeria}

So far, there has been no separate standard for SMEs in Nigeria. Differential reporting is yet to be adopted in Nigeria. Thus for SMEs, the only concession that has been made to reduce the burden of financial reporting is the one made by statute namely, in the Companies and Allied Matters Act (CAMA) 1990 as amended.

It is reiterated here, that according to section 351(1) of CAMA 1990, a company qualifies as small in a year if for that year, the conditions stated earlier holds.

Section 350(1) of CAMA 1990 permits companies classified above (as small) to deliver modified financial statements in accordance with Part I of the Seventh Schedule of CAMA 1990.

Part I of the seventh schedule of CAMA 1990 provides that:

1. (1) In respect of the relevant financial year, there may be delivered a modified balance sheet, instead of a full balance sheet.

(2) The modified balance sheet shall be an abbreviated version of the full balance sheet, showing only those items to which a letter of roman number is assigned to in the balance sheet format adopted under the Second Schedule Part I (such items include: called up share capital not paid; own shares; concession, patents, licenses, trademarks and similar rights and assets; goodwill; debtors; prepayments and accrued income; called up share capital; reserve for own shares; retained earnings; debenture loans; payments received in advance; provision for taxation; and accruals and deferred income), of this Act but in other respects corresponding to the full balance sheet.

(3) The copy of the modified balance sheet shall be signed as required by Section 343 of this Act.

2. A copy of the company's profit and loss account need not be delivered nor a copy of the directors' report.

3. The information required in Parts V and VI of the Third Schedule of the Act need not be given.

4. The information required by the Third schedule of this Act to be given in the notes to the account need not be given, with the exception of any information required by the following provision, of that schedule-

Paragraph 36 (accounting policies)

Paragraph 38 (share capital)

Paragraph 39 (particulars of allotments)

Paragraph 47 (1) and (4) (particulars of debts)

Paragraph 57(1) (basis of translation of foreign currency amount in naira); and

Paragraph 57 (corresponding amounts of preceding year); and the reference here to paragraph $52(2)$ includes that sub paragraph as applied to any items stated in note to the accounts, whether by virtue of a requirement of the Third Schedule or under any other provision of this Act.

5. If a modified balance sheet is delivered, there shall be disclosed in its (or in a note to the company's accounts delivered)-

(a) The aggregate of the amounts required by note (5) of the notes on the balance sheet formats set out in the second schedule Part I to be shown separately for each item included under debtors (amount falling due after one year); and

(b) The aggregate of the amounts required by noted (13) of those notes to be shown separately for each item included under creditors in format (2) (amounts falling due within one year or after more than one year).

6. The company's balance sheet shall contain a statement by the directors that -

(a) They rely on Sections 350 to 353 of this Act as entitling them to deliver modified accounts; and

(b) They do so, on the ground that the company is entitled to the benefit of those sections as a small company, and the statement shall appear in the balance sheet immediately above the signatures of the directors.

7. (1) The accounts delivered shall be accompanied by a special report of the auditors stating that in their opinion-

(a) The directors are entitled to deliver modified accounts in respect of the financial year, as claimed in the directors' statement. 
(b) Any accounts comprised in the documents delivered as modified accounts are properly prepared as such in accordance with this schedule.

(2) A copy of the auditor's report under section 359 of this Act need not be delivered, but the full text of it shall be reproduced in a special report under this paragraph.

(3) If the directors propose to rely on sections 350 to 353 of this Act as entitling them to deliver modified accounts, it shall be the auditors duty to provide them with a report stating whether in their opinion the directors are so entitled and whether the documents to be delivered as modified accounts are properly prepared in accordance with this Act.

8. Subject as above, where directors rely on sections 350 to 353 of the Act in delivering any documents, and-

(a) The company is entitled to the benefit of these sections on the ground claimed by the directors in their statement under paragraph 6; and

(b) The accounts compiled in the documents are properly prepared in accordance with this schedule, then section 354(3) of this Act will have effect as if any document which by virtue of this part of this schedule is included in or omitted from the documents delivered as modified accounts were (or, as the case may be were not required by this Act to be comprised in the company's accounts in respect of the year.

From the above, it can be concluded that the model of financial reporting available (not necessarily adopted by) for SMEs in Nigeria is the single set of GAAP with exclusions from certain standards for SMEs. However more can still be done in terms of the financial reporting disclosures for SMEs.

\section{Research Methodology}

The survey method of research design was adopted in this study and the population consisted of fifty (50) respondents drawn from among three broad groups: Auditors, Financial Analysts-Stockbrokers and Preparers of Financial Statements. The main instrument used for the collection of data in this study was the questionnaire, which was designed in five response options of Likert-scale. The questions are differently designed to reflect the various objectives but they are tested together with the same methods and their results analyzed as part of the whole study. The methods used in data analysis were actual response analysis, analysis in relation to specific problem, percentage analysis and chi-square $\left(\mathrm{X}^{2}\right)$.

\section{Test of Hypotheses}

$\mathbf{H}_{\mathbf{0}}$ 1: $\quad$ The costs of adopting a single set of GAAP without exclusions do not outweigh its benefits.

In testing this hypothesis, the data generated were used and the result obtained is presented in the table 1 below:

\begin{tabular}{|l|l|l|l|l|l|}
\hline Responses & Agreed & Undecided & Disagreed & $\begin{array}{l}\text { Strongly } \\
\text { Disagreed }\end{array}$ & Total \\
\hline $\begin{array}{l}\text { Strongly } \\
\text { Agreed }\end{array}$ & 9 & 3 & 11 & 6 & 35 \\
\hline 6 & 6 & 4 & 7 & 17 & 35 \\
\hline 1 & 5 & 4 & 6 & 3 & 35 \\
\hline 17 & $\mathbf{2 0}$ & $\mathbf{1 1}$ & $\mathbf{2 4}$ & $\mathbf{2 6}$ & $\mathbf{1 0 5}$ \\
\hline $\mathbf{2 4}$ & & &
\end{tabular}

Source: Researcher's Fieldwork, 2014.

The chi-square $\left(\mathrm{X}^{2}\right)$ test at $95 \%$ confidence interval was employed to test the hypothesis.

Level of significance $(\propto)=0.05$.

Degree of freedom $(\mathrm{df})=(\mathrm{R}-1)(\mathrm{C}-1)$

$$
\begin{aligned}
& =(3-1)(5-1) \\
& =(2)(4)=8
\end{aligned}
$$

Since the degree of freedom (df) is 8 , the critical value using the chi-square table is 15.507.

\begin{tabular}{|l|l|l|l|l|l|}
\hline Cells & $\mathbf{O}$ & $\mathbf{E}$ & $\mathbf{O - E}$ & $(\mathbf{O}-\mathbf{E})^{2}$ & $\frac{(\mathbf{O}-\mathbf{E})^{2}}{\mathbf{E}}$ \\
\hline $\mathrm{R}_{1} \mathrm{C}_{1}$ & 6 & 8.0 & $(2.00)$ & 4.00 & 0.500 \\
\hline $\mathrm{R}_{1} \mathrm{C}_{2}$ & 9 & 6.7 & 2.30 & 5.29 & 0.789 \\
\hline $\mathrm{R}_{1} \mathrm{C}_{3}$ & 3 & 3.7 & $(0.70)$ & 0.49 & 0.132 \\
\hline $\mathrm{R}_{1} \mathrm{C}_{4}$ & 11 & 8.0 & 3.00 & 9.00 & 1.125 \\
\hline $\mathrm{R}_{1} \mathrm{C}_{5}$ & 6 & 8.7 & $(2.70)$ & 7.29 & 0.837 \\
\hline $\mathrm{R}_{2} \mathrm{C}_{1}$ & 1 & 8.0 & $(7.00)$ & 49.00 & 6.125 \\
\hline $\mathrm{R}_{2} \mathrm{C}_{2}$ & 6 & 6.7 & $(0.70)$ & 0.49 & 0.073 \\
\hline $\mathrm{R}_{2} \mathrm{C}_{3}$ & 4 & 3.7 & 0.30 & 0.09 & 0.024 \\
\hline $\mathrm{R}_{2} \mathrm{C}_{4}$ & 7 & 8.0 & $(1.00)$ & 1.00 & 0.125 \\
\hline $\mathrm{R}_{2} \mathrm{C}_{5}$ & 17 & 8.7 & 8.30 & 68.89 & 7.918 \\
\hline $\mathrm{R}_{3} \mathrm{C}_{1}$ & 17 & 8.0 & 9.00 & 81.00 & 10.125 \\
\hline $\mathrm{R}_{3} \mathrm{C}_{2}$ & 5 & 6.7 & $(1.70)$ & 2.89 & 0.431 \\
\hline
\end{tabular}




\begin{tabular}{|l|l|l|l|l|l|}
\hline $\mathrm{R}_{3} \mathrm{C}_{3}$ & 4 & 3.7 & 0.30 & 0.09 & 0.024 \\
\hline $\mathrm{R}_{3} \mathrm{C}_{4}$ & 6 & 8.0 & $(2.00)$ & 4.00 & 0.500 \\
\hline $\mathrm{R}_{3} \mathrm{C}_{5}$ & 3 & 8.7 & $(5.70)$ & 32.49 & 3.734 \\
\hline$\Sigma$ & & & & & $\mathbf{X}^{2}=\mathbf{3 2 . 4 6 2}$ \\
\hline
\end{tabular}

Source: Researcher's Computations from Table 1

Expected frequency $(\mathrm{E})$ is calculated using the formula

Row Total x Column Total

Grand Total

\section{Graphical Presentation}

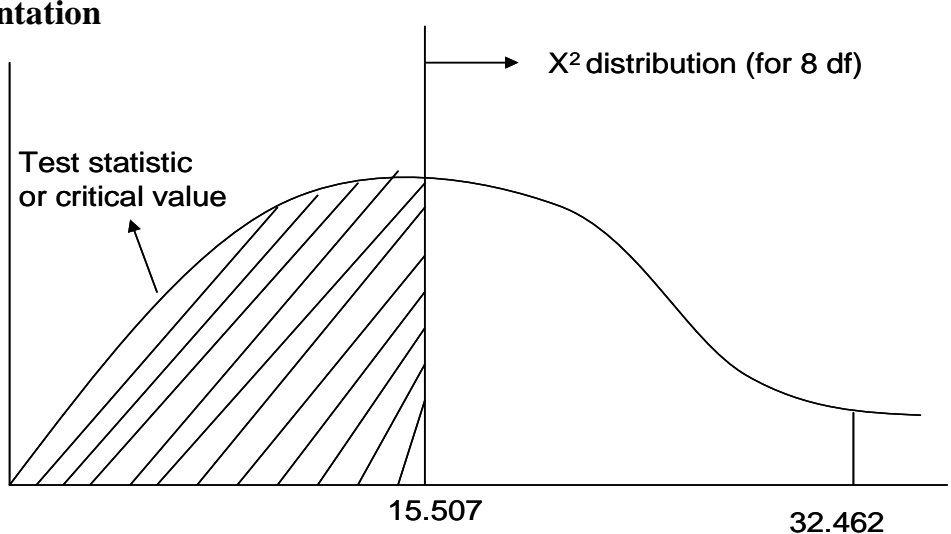

Decision: Reject Ho since the calculated value of $\mathrm{X}^{2}\left(\mathrm{X}^{2} \mathrm{cal}\right)$ of 32.462 is greater than the critical value of 15.507implying that the costs of adopting a single set of GAAP without exclusions outweigh its benefits.

$\mathbf{H}_{\mathbf{O}}$ 2: The costs of adopting a single set of GAAP with exclusions from certain standards for SMEs do not outweigh its benefits.

Table 2

\begin{tabular}{|l|l|l|l|l|l|}
\hline Responses & Agreed & Undecided & Disagreed & $\begin{array}{l}\text { Strongly } \\
\text { Disagreed }\end{array}$ & Total \\
\hline $\begin{array}{l}\text { Strongly } \\
\text { Agreed }\end{array}$ & 13 & 4 & 7 & - & 35 \\
\hline 11 & 9 & 6 & 9 & 4 & 35 \\
\hline 4 & 15 & 6 & 2 & 3 & 35 \\
\hline 9 & $\mathbf{3 9}$ & $\mathbf{1 6}$ & $\mathbf{1 8}$ & $\mathbf{7}$ & $\mathbf{1 0 5}$ \\
\hline $\mathbf{2 4}$ & &
\end{tabular}

Source: Researcher's Fieldwork, 2014.

The chi-square $\left(\mathrm{X}^{2}\right)$ test at $95 \%$ confidence interval was employed to test the hypothesis.

Level of significance $(\propto)=0.05$

Degree of freedom $(\mathrm{df})=(\mathrm{R}-1)(\mathrm{C}-1)$

$$
\begin{aligned}
& =(3-1)(5-1) \\
& \text { (2) }(4)=8
\end{aligned}
$$

Since the degree of freedom (df) is 8, the critical value using the chi-square table is 15.507.

\begin{tabular}{|l|l|l|l|l|l|}
\hline Cells & $\mathbf{O}$ & $\mathbf{E}$ & $\mathbf{O}-\mathbf{E}$ & $(\mathbf{O}-\mathbf{E})^{2}$ & $\frac{(\mathbf{O}-\mathbf{E})^{2}}{\mathbf{E}}$ \\
\hline $\mathrm{R}_{1} \mathrm{C}_{1}$ & 11 & 8.0 & 3.00 & 9.00 & 1.125 \\
\hline $\mathrm{R}_{1} \mathrm{C}_{2}$ & 13 & 13.0 & 0.00 & 0.00 & 0.000 \\
\hline $\mathrm{R}_{1} \mathrm{C}_{3}$ & 4 & 5.3 & $(1.30)$ & 1.69 & 0.319 \\
\hline $\mathrm{R}_{1} \mathrm{C}_{4}$ & 7 & 6.0 & 1.00 & 1.00 & 0.167 \\
\hline $\mathrm{R}_{1} \mathrm{C}_{5}$ & 0 & 2.7 & $(2.70)$ & 7.29 & 2.700 \\
\hline $\mathrm{R}_{2} \mathrm{C}_{1}$ & 4 & 8.0 & $(4.00$ & 16.00 & 2.000 \\
\hline $\mathrm{R}_{2} \mathrm{C}_{2}$ & 11 & 13.0 & $(2.00)$ & 4.00 & 0.308 \\
\hline $\mathrm{R}_{2} \mathrm{C}_{3}$ & 6 & 5.3 & 0.70 & 0.49 & 0.92 \\
\hline $\mathrm{R}_{2} \mathrm{C}_{4}$ & 9 & 6.0 & 3.00 & 9.00 & 1.500 \\
\hline $\mathrm{R}_{2} \mathrm{C}_{5}$ & 5 & 2.7 & 2.30 & 5.29 & 1.959 \\
\hline $\mathrm{R}_{3} \mathrm{C}_{1}$ & 9 & 8.0 & 1.00 & 1.00 & 0.125 \\
\hline $\mathrm{R}_{3} \mathrm{C}_{2}$ & 15 & 13.0 & 2.00 & 4.00 & 0.308 \\
\hline $\mathrm{R}_{3} \mathrm{C}_{3}$ & 6 & 5.3 & 0.70 & 0.49 & 0.092 \\
\hline $\mathrm{R}_{3} \mathrm{C}_{4}$ & 2 & 6.0 & $(4.00)$ & 16.00 & 2.667 \\
\hline $\mathrm{R}_{3} \mathrm{C}_{5}$ & 3 & 2.7 & 0.30 & 0.09 & 0.033 \\
\hline$\sum$ & & & & & $\mathbf{X}^{2}=\mathbf{1 3 3 9 5}$ \\
\hline
\end{tabular}

Source: Researcher's Computations from Table 2 


\section{Graphical Presentation}

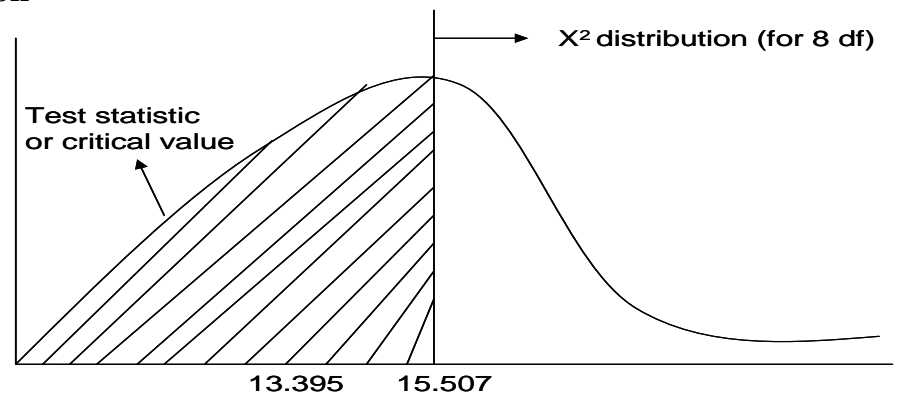

Decision: Accept Ho since the calculated value of $\mathrm{X}^{2}$ is less than the critical value (that is, $13.395<15.507$ ), implying that the costs of adopting a single set of GAAP with exclusion from certain standards for SMEs do not outweigh its benefits.

$\mathbf{H}_{\mathbf{O}}$ 3: The costs of adopting two sets of GAAP (big GAAP and little GAAP) do not outweigh its benefits.

Table 3

\begin{tabular}{|l|l|l|l|l|l|}
\hline Responses & Agreed & Undecided & Disagreed & $\begin{array}{l}\text { Strongly } \\
\text { Disagreed }\end{array}$ & Total \\
\hline $\begin{array}{l}\text { Strongly } \\
\text { Agreed }\end{array}$ & 8 & 3 & 11 & 5 & 35 \\
\hline 8 & 8 & 7 & 9 & 6 & 35 \\
\hline 5 & 13 & 7 & 3 & 5 & 35 \\
\hline 7 & $\mathbf{2 9}$ & $\mathbf{1 7}$ & $\mathbf{2 3}$ & $\mathbf{1 6}$ & $\mathbf{1 0 5}$ \\
\hline $\mathbf{2 0}$ & & & & \\
\hline
\end{tabular}

Source: Researcher's Fieldwork, 2014.

The chi-square test at $95 \%$ confidence level is employed to test the hypothesis.

Level of significance $(\propto)=0.05$

Degree of freedom $(\mathrm{df})=(\mathrm{R}-1)(\mathrm{C}-1)$

$(3-1)(5-1)$

(2) $(4)=8$

Since the degree of freedom (df) is 8 , "the critical value using the chi-square table is 15.507 .

\begin{tabular}{|l|l|l|l|l|l|}
\hline Cells & $\mathbf{O}$ & $\mathbf{E}$ & $\mathbf{O}-\mathbf{E}$ & $(\mathbf{O}-\mathbf{E})^{2}$ & $\frac{(\mathbf{O}-\mathbf{E})^{2}}{\mathbf{E}}$ \\
\hline $\mathrm{R}_{1} \mathrm{C}_{1}$ & 8 & 6.7 & 1.30 & 1.69 & 0.252 \\
\hline $\mathrm{R}_{1} \mathrm{C}_{2}$ & 8 & 9.7 & $(1.70)$ & 2.89 & 0.298 \\
\hline $\mathrm{R}_{1} \mathrm{C}_{3}$ & 3 & 5.7 & $(2.70)$ & 7.29 & 1.279 \\
\hline $\mathrm{R}_{1} \mathrm{C}_{4}$ & 11 & 7.7 & 3.30 & 10.89 & 1.414 \\
\hline $\mathrm{R}_{1} \mathrm{C}_{5}$ & 5 & 5.3 & $(0.30)$ & 0.09 & 0.017 \\
\hline $\mathrm{R}_{2} \mathrm{C}_{1}$ & 5 & 6.7 & $(1.70)$ & 2.89 & 0.431 \\
\hline $\mathrm{R}_{2} \mathrm{C}_{2}$ & 8 & 9.7 & $(1.70)$ & 2.89 & 0.298 \\
\hline $\mathrm{R}_{2} \mathrm{C}_{3}$ & 7 & 5.7 & 1.30 & 1.69 & 0.296 \\
\hline $\mathrm{R}_{2} \mathrm{C}_{4}$ & 9 & 7.7 & 1.30 & 1.69 & 0.219 \\
\hline $\mathrm{R}_{2} \mathrm{C}_{5}$ & 6 & 5.3 & 0.70 & 0.49 & 0.092 \\
\hline $\mathrm{R}_{3} \mathrm{C}_{1}$ & 7 & 6.7 & 0.30 & 0.09 & 0.013 \\
\hline $\mathrm{R}_{3} \mathrm{C}_{2}$ & 13 & 9.7 & 3.30 & 10.89 & 1.123 \\
\hline $\mathrm{R}_{3} \mathrm{C}_{3}$ & 7 & 5.7 & 1.30 & 1.69 & 0.296 \\
\hline $\mathrm{R}_{3} \mathrm{C}_{4}$ & 3 & 7.7 & $(4.70)$ & 22.09 & 2.869 \\
\hline $\mathrm{R}_{3} \mathrm{C}_{5}$ & 5 & 5.3 & $(0.30)$ & 0.09 & 0.017 \\
\hline$\sum$ & & & & & $\mathbf{X}^{2}=\mathbf{8 . 9 1 4}$ \\
\hline
\end{tabular}

Source: Researcher's Computations from Table 3

\section{Graphical Presentation}

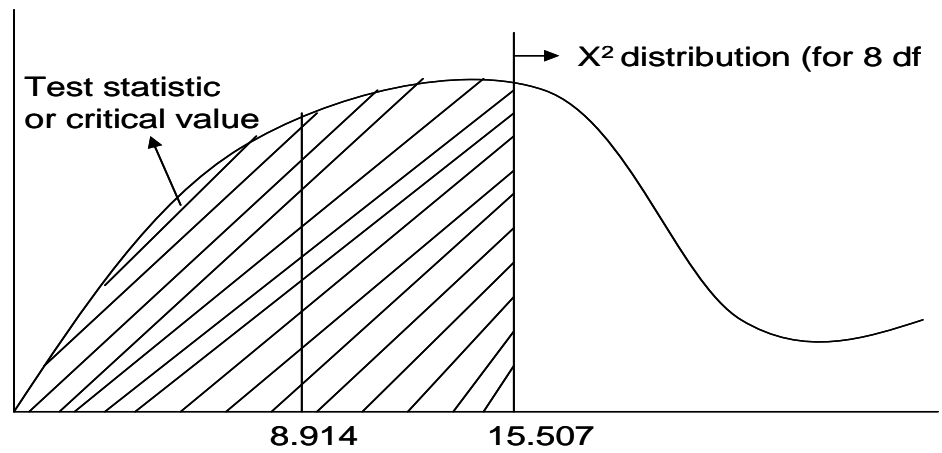

www.iosrjournals.org 
Decision: Accept Ho since the calculated value of $X^{2}\left(X^{2}\right.$ cal) of 8.914 is less than the critical value of $X^{2}\left(X^{2} c r\right)$ of 15.507, implying that the costs of adopting two sets of GAAP (big GAAP and little GAAP) do not outweigh its benefits.

\section{Summary, Conclusions And Recommendations}

This study was undertaken to provide answers to questions such as whether the cost of preparing financial statements for small and medium scale enterprises (SMEs) in Nigeria will exceed the benefits. The aim of the study as disclosed earlier was to ascertain the weaknesses of the current financial reporting system for SMEs and to determine whether having a separate financial reporting system will be acceptable to users of SME financial statements, amongst others. The study therefore revealed that the current financial reporting system whereby there is a single set of standard with some exemptions for SMEs is satisfactory, also there is a high preference for the use of a single set of GAAP with exclusion from certain standards for SMEs in preparing SME financial statement followed by two sets GAAP (big GAAP and little GAAP). The least preferred alternative is a single set of GAAP without exclusion. The study also revealed that using a single set of GAAP with exclusion will in order of importance produce the following benefits: simplicity and cost reduction, reduction in delay and increased relevance to the organization and thatthe current financial reporting system in Nigeria is still the most preferred financial reporting model by SMEs in Nigeria. This is perhaps because it lies between the two extremes of absolute differential reporting and no differential reporting. It was also however revealed that improvement could be made on this preferred model so as toachieve its ultimate purpose of exempting SMEs from reporting economic events and transactions that they do not deal with. In the light of the findings obtained in this study, the following recommendations are advanced:

* SMEs should be encouraged to adopt the current financial reporting system so as to take advantage of the benefits of simplicity, reduction in cost and delay, as well as the increase in the relevance of the financial statements to the enterprise.

- To ease the burden of producing financial statements, SMEs should be allowed to exclude the statement of accounting policies, value added statement, notes on the accounts, and the directors' report from their financial statements.

* The Nigerian Accounting Standard Board (NASB) should set up a separate committee to deal with financial reporting for SMEs.

\section{References}

[1]. Accountancy (1999) 'Financial reporting standards for smaller entities (Effective March, 1999)', Accountancy, Vol.123, No.1265 Pp.88-121.

[2]. Accounting Standards Board (1999) Statement of Principles for Financial Reporting.Companies and Allied Matters Act, 2004, Lagos, Government Printers

[3]. Deloitte and Touché (n.d.) 'Financial reporting - a time to refocus, Finance Magazine Online.

[4]. Epstein, B.J. and Jermakowicz, E.K. (2007) 'International standards for small and mediumsized entities: analyzing the IASB exposure draft, The CPA Journal, New York.

[5]. Financial Management (1997a) 'Financial reporting standard for smaller entities', FinancialManagement, Vol.75, No.1, Pp.4-5.

[6]. Financial Management (1997b) 'ASB plans for accounting for smaller entities', FinancialManagement, Vol.75 No.9, Pp.3

[7]. Financial Management (1997c) 'Financial reporting standard for smaller entities', Financial Management, Vol.75, No.11, Pp.6.

[8]. Financial Management (2000) 'Revised Standard for Small Entities as cited in Reid, G.C. and Smith, J.A. (n.d) 'Practitioner views on financial reporting for smaller entities', Small Business Economics.

[9]. Financial Management (2002) 'ASB issues revised FRSSE', Financial Management, 4.

[10]. Ilaboya, O.J. (2005) Advanced Financial Accounting, Ibadan, Dalag Prints and Packaging Limited, Pp.167-177.

[11]. Jameson, M. (1990) A Practical Guide to Creative Accounting, London, Kogan Page.

[12]. Maingot, M. and Zeghal, D. (2006) 'Financial reporting of small business entities in Canada',Journal of Small Business Management, Vol. 44, No.4.

[13]. Ogbe, N.E. (1985) The Promotion and Development of SMEs in Nigeria: An address Presentedat the First National Workshop, Administrative Staff College of Nigeria (ASCON), Badagry, $4^{\text {th }}$ March.

[14]. Sacco, J. (1997) Financial Reporting in Government (s.n)

[15]. Sleigh-Johnson, N. (2001) 'Financial reporting - accounting issues - in defense of the FRSSE', Accountancy, Vol.128, No.1300 Pp.92. 